\title{
РОССИЙСКОЕ ОБЩЕСТВО
}

DOI: $10.17805 / z p u .2016 .3 .1$

\section{O «правильном образовании» для России XXI века}

\author{
И. М. ИЛЬИНСКИЙ \\ (МОСКОВСКИЙ ГУМАНИТАРНЫЙ УНИВЕРСИТЕТ)
}

В статье представлены размышления по острым проблемам российского образования. Автор обосновывает приверженность к классическому методу обучения (аудитория - студент - преподаватель - семинары - практика и т. д.), на которых базируется работа Московского гуманитарного университета. Метод не только оправдал себя за долгие годы, в том числе в период реформирования образования в России, но и считается предпочтительным самими студентами. Вопреки распространенному представлению об образовании и воспитании как автономных процессах образование должно стать единым целенаправленным процессом.

Актуальной проблемой является развитие исследовательского образования, которое должно быть стратегической задачей и общества, и государства. Надо говорить далеко не обо всех обучающихся, а об определенных группах школьников и студентов, перспективных с точки зрения овладения современным знанием. Российское общество спасет только подготовка значительной части выпускников школ, среднего профессионального и высшего образования, способных понимать окружающий мир и происходящее в нем, способных творить.

В правильной системе образования необходим баланс равновеликих и взаимодополняющих подсистем точных и естественных наук, с одной стороны, и общественных и гуманитарных - с другой. Сегодня утрачено правильное соотношение между этими подсистемами. Следует преодолеть недооценку общественного и гуманитарного знания в современном образовании и осознать дисбаланс подсистем как еще одну глобальную проблему человечества.

Ключевые слова: правильное образование; высшее образование; проблема понимания; российское образование; проблема воспитания; проблемы российского образования; проблемы российского общества; глобальные проблемы

\section{ВВЕАЕНИЕ}

$\Pi$ едагогика и образование заинтересовали меня задолго до того, как я стал ректором. В 1952 г. я окончил Новосибирский строительно-монтажный техникум, в 1958 г. - Омское танко-техническое училище и в сентябре того же года поступил на заочное отделение Новосибирского института инженеров железнодорожного транспорта, где проучился шесть лет, работая слесарем, старшим мас- 
тером, освобожденным секретарем комитета комсомола огромной стройки, первым секретарем райкома комсомола, и в 28 лет был назначен начальником цеха оборонного завода п/я 23, выпускавшего ракеты типа «земля-воздух». Однако через несколько месяцев был отозван на работу в Центральный комитет В $\Lambda \mathrm{KCM}$, в Москву. Через пять с небольшим лет мне доверили должность главного редактора Всесоюзного журнала «Комсомольская жизнь» с месячным тиражом почти в 3 млн экземпляров. Не случайно: уже тогда у меня был немалый журналистский стаж - лет 15 публиковался в центральных газетах и журналах по различным волновавшим меня темам. В основном это была научная публицистика, зачастую довольно жесткая, по поводу чего меня не раз «прорабатывали» в различных учреждениях.

В сорокалетнем возрасте, в сентябре 1975 г., снова стал «студентом»- слушателем Аипломатической академии Министерства иностранных дел СССР, пройдя конкурс из 19 человек на место. В 1977 г. я с отличием окончил Академию, успев за это время завершить заочное отделение аспирантуры Института народного хозяйства им. Г. В. Плеханова и получить степень кандидата исторических наук.

Несмотря на весь шик-блеск, дипломатия меня разочаровала. Зато манила наука. Предложение занять должность заведующего отделом Научно-исследовательского центра Высшей комсомольской школы (как было сказано: «С перспективой...») я принял с радостью. С первых месяцев работы я понял, что это мое: осмысливать происходящее, создавать научные проекты, организовывать тебе подчиненных исследователей на их реализацию - занятие крайне увлекательное. Надо много знать, много читать, увлекать других своими идеями. Аа, это главная стезя моей жизни.

«Но при чем тут педагогика, образование?» - вероятней всего уже воскликнул читатель. В каком-то смысле он прав: я несколько затянул вступление к статье. Возможно. Однако мне хотелось показать, что мои заметки не навеяны случайными ветрами конъюнктуры, а выношены многолетними наблюдениями изнутри образовательного процесса во времена как советские, так и нынешние. В Высшей комсомольской школе, став заместителем, а вскоре директором Научно-исследовательского центра, я много лет был членом ректората и знал об образовательном процессе в этом элитном заведении почти все. В течение учебного года читал на английском языке курс лекций иностранным слушателям, которые обучались в ВКШ. Был момент, когда мне поручили в течение трех месяцев вести занятия с единственным «секретным слушателем» - первым секретарем ЦК Аемократической организации Афганистана. В течение двух лет (1982-1984 гг.) я был секретарем парткома ВКШ, что, согласно ст. 6 Конституции СССР, формально ставило меня вровень с ректором, более того, давало право контроля за деятельностью администрации...

Наконец, быть может, главное: во всех образовательных заведениях, где мне пришлось учиться, я наблюдал учителей и преподавателей самых разных калибров: плохих, слабых, средних, хороших, отличных и выдающихся. Одинаковую работу одни выполняли с душой и глубокими знаниями, другие - с безразличием, читая тексты по замусоленным конспектам. То, что это были, как правило, люди разные по способностям от природы, я понимах. Но я замечал и то, что большинство и не старалось стать лучше. Педагогика не была их призванием. 
А потом, когда в свою раннюю молодость я вдруг оказался руководителем сначала на производстве, а потом на общественной (комсомольской) работе, понял, что я тоже «педагог», хоть и несколько в другом смысле: обучаю и образую людей (уже взрослых!) не 45 минут или пару учебных часов, а целыми днями, месяцами и годами: убеждаю, поощряю, требую, наказываю и т. А. Значит, должен быть педагогически образован и воспитан.

Вот тогда, еще обучаясь инженерному делу, я познакомился с трудами Аристотеля, Ж.-Ж. Руссо, Я. А. Коменского, К. А. Ушинского, А. С. Макаренко и других выдающихся педагогов, философов и мыслителей. Со временем, когда я работал уже в Москве, мои статьи о проблемах молодежи стали появляться в газетах «Комсомольская правда», «Известия», «Аитературная газета», журнале «Молодой коммунист» и собственно научных периодических изданиях - «Педагогика», «Социологические исследования».

Отработав около пяти лет заместителем, а затем еще 10 лет директором Научно-исследовательского центра при Институте молодежи, в феврале 1994 г. я был назначен ректором Института молодежи, находившегося на краю гибели. На моем рабочем столе появилась табличка: «У нас нет денег. Мы должны думать...»

Размышляя о постсоветских «реформах», «модернизациях» и разного рода пертурбациях системы высшего образования, я пришел к некоторым выводам, которые хочу изложить в этих беглых заметках по наиглавнейшим, как я считаю, позициям фундаментального, стратегического характера.

На полновесный разговор по этой теме я сейчас не решаюсь, поскольку это работа на год, а то и годы. Между тем меня ждут уже многостраничные наброски давно задуманной книги, не без труда собранная по этой теме и не вся еще прочитанная литература по более глобальному вопросу. Разного рода срочные дела отвлекали меня, но теперь я должен довести дело до конца. Это и заставляет меня извиниться перед читателем за беглость моего повествования, сказать о том, что уже поэтому я не претендую на «конечную истину» в своих суждениях и выводах, во всяком случае, в ряде сложных сюжетов, требующих и глубокой аргументации.

\section{1. О КААССИЧЕСКОМ ОБРАЗОВАНИИ}

Все годы руководства вузом я утверждал приверженность прежде всего классическому методу образования (аудитория - студент - преподаватель - семинары - практика и т. д.), отвергая идеи перевода образовательного процесса преимущественно на дистанционные формы обучения. Более того, мои хорошие товарищи М. П. Карпенко, ректор ННОУ «Современная гуманитарная академия» (СГУ), В. П. Тихомиров, ректор МЭСИС, - доктора технических наук, профессора, высокообразованные в области дистанционного обучения, уже имевшие в своих вузах контингент по 100-160 тыс. студентов, страстно убеждали меня, что классический метод вот-вот умрет, что будущее, несомненно, за дистанционным обучением, и предлагали мне всемерную помощь в освоении новой формы обучения.

Признаться, временами я колебался... Ведь то, что абсолютное большинство людей сегодня понимает как образование (то же дистанционное обучение), и то, чем это обучение, если не сказать - все нынешнее образование, фактически является, далеко друг от друга. Это несоответствие приняло вызывающие формы. Все 
дело в том, что выстраивание образования в русле рыночных отношений в основном разрушило сущность классического подхода. Из процесса обучения вымываются творческая функция обучающего и обучаемого, связь обучения с исследованиями и мотивация к ним. Рыночный подход подавляет в обучающемся стремление к самовоспитанию, построению собственного духовного мира, выработке гражданской и патриотической позиции.

Прошли годы... И все-таки прав оказался я. СГУ со скандалом закрыли, МЭСИС слили с «Плехановкой». Наш вуз (пока! в жизни все «пока») - существует. Выходит, мы выбрали правильную стратегию.

Но экономика в России все-таки рыночная, и потому «музыку» (качество образования) заказывает работодатель. На Западе дистанционное образование, говорят, востребовано. В новом законе «Об образовании в РФ» по этому поводу есть специальная статья.

Признаться, я скептически отношусь к разделению образования на бакалавриат, магистратуру и аспирантуру как третий уровень образования. Однако мы ответственно все выполняем. Иначе действовать нельзя.

Но вот в мае - июне 2014 г. МГУ им. М. В. Аомоносова провел комплексное социологическое исследование «Современная система высшего образования глазами студентов, аспирантов и профессорско-преподавательского состава МГУ имени М. В. Аомоносова»1. Инструментарий исследования составили три вида анкет. При помощи массовой социологической анкеты опрошены 4814 студентов 1-5-го курсов 39 факультетов; при помощи анкеты аспирантов - 453 аспиранта разных лет обучения; экспертной анкеты - 1079 экспертов, в том числе 1000 преподавателей, 40 заведующих кафедрами и 39 деканов факультетов.

Ознакомившись с результатами этого исследования, я возрадовался! Аля меня оно является авторитетнейшим. Ведь его возглавили ректор МГУ, президент Российского союза ректоров, академик РАН В. А. Садовничий и директор главного социологического института страны - Института социально-политических исследований РАН - академик РАН Г. В. Осипов. Это вам не ВЦИОМ и не « Аевада-центр», готовые опросить кого угодно и представить заказчику какие ему угодно цифры и комментарии. Не менее важно и то, что опрошены были студенты всех факультетов МГУ им. М.В. Аомоносова, куда со всей России стекается основная масса «стобалльников» по ЕГЭ, которых принято считать самыми головастыми выпускниками школ, плюс 1079 экспертов - сотрудников МГУ, которых в большинстве надобно отнести к интеллектуальной и духовной элите образовательного сообщества России, да и всей страны.

Из названного исследования следует несколько чрезвычайно важных выводов:

1. Развитие сотрудничества вузов и бизнес-сектора приводит к изменениям в самом содержании обучения. Считается, что растет спрос на узких специалистов, владеющих конкретным набором умений и навыков, требуемых работодателем, вследствие чего начался переход к компетентностному подходу в обучении. Тенденция к узкой специализации приводит к тому, что образование нацеливается не на получение студентом широких теоретических познаний общенаучного характера, а на умение использовать компьютерную технику для быстрого точечного поиска необходимой информации. И хотя узкая специализация, несомненно, необходима - спорить с этим глупо, однако я всегда думал и остаюсь на 
точке зрения Козьмы Пруткова до сих пор: «Специалист подобен флюсу: полнота того и другого односторонняя». Высшая школа, как и средняя, образует человека, гражданина, патриота и, разумеется, компетентного специалиста. Как это сделать в одно и то же время - это трудный вопрос. Вот его и надо бы решать в ходе реформ.

2. Внедряемый в высшее образование компетентностный и узкоспециализированный подход также стал предметом обсуждения как в среде экспертов, так и среди студентов. По мнению экспертов, студент в первую очередь должен обладать широкими познаниями в ряде смежных областей $(49,5 \%)$, затем - умением найти информацию в нужный момент, даже не имея достаточных знаний $(31,1 \%)$, и в последнюю очередь - узкоспециализированными знаниями $(12,9 \%)$.

3. Практически единодушно отрицательным было мнение всего университетского сообщества по поводу изменения статуса аспирантуры: с 1 сентября 2013 г. она лишилась статуса послевузовского образования и стала третьей ступенью высшего образования или некоей вариацией магистратуры. Тем самым аспирантура формально перестала быть каналом подготовки научных и преподавательских кадров высшей квалификации. (Аобавлю: а также введение бакалавриата и магистратуры, что является поспешным решением России о присоединении к так называемому Болонскому процессу.)

Сегодняшние аспиранты МГУ оценили эту реформу как свидетельство снижения статуса науки и ее низкой востребованности в обществе. В такой ситуации не может быть и речи о «прорывных» научных разработках, о собственных новейших технологиях, об инновационном развитии страны.

4. Примечательны в свете вышесказанного ответы студентов на мировоззренческие вопросы: 77,2\%, т. е. подавляющее большинство из них, убеждены, что у России свой путь развития, отличный от стран Запада, только 18,2\% считают, что Россия должна идти по пути западных стран.

5. Более трети респондентов отметили снижение уровня общей культуры студентов (48,3\%), уровня знаний студентов $(38,6 \%)$, морально-нравственного уровня студентов $(37,4 \%)$, командного духа, студенческого единения $(37,3 \%)$, а также формирования гражданской идентичности $(33,7 \%)$.

6. И наконец, вывод, имеющий самое прямое отношение к данному разделу статьи. Оценивая отношение к различным способам организации учебного процесса, большинство студентов отдали свои предпочтения классическому учебному процессу: лекции, семинары, курсовые, экзамены - 56,6\% и производственной практике - 52,5\%. Наименее предпочитаемая студентами форма учебы - дистанционное обучение: $47,7 \%$ оценили ее как наименее полезную.

Такие мероприятия, как полный переход на Авухуровневую систему высшего образования, ухудшат, считают студенты, качество университетского образования.

Практически единодушно (90\% и более) эксперты негативно оценивают последствия таких мероприятий реформирования высшего образования, как рассмотрение образования в категориях рынка ( «образовательные услуги», «студент-клиент»), отмена вступительных экзаменов для поступающих на платной основе и др.

Значит ли все это, что наш университет упрямо стоит на «чисто классическом» подходе к образованию, уперев рога в землю? Конечно нет. Мы умеренно 
(а надо бы побыстрей и масштабней) развиваем электронное образование, используем интернет-рекламу, внедряем электронные формы в управленческой деятельности и т. А.

Считаю, что умеренность в современном сложном и усложняющемся, быстро развивающемся, меняющемся и ускоряющемся мире - это спасительная позиция. «Мера - дар богов», - говорили еще древние греки.

\section{2. ОБРАЗОВАНИЕ КАК ЕАИНЫЙ ЦЕАЕНАПРАВАЕННЫЙ ПРОЦЕСС ВОСПИТАНИЯ И ОБУЧЕНИЯ}

В 2015 г. состоялся очередной съезд Российского союза ректоров, на котором работала секция «Образование и воспитание». Председательствовала на ней президент Российской академии образования $\Lambda$. И. Вербицкая.

Прочитав перед началом заседания название секции, удивился: «Как можно так написать - образования и ...воспитания»? Ведь давным-давно научным сообществом принято считать, что «образование - это единый целенаправленный процесс воспитания и обучения». «Наверное, кто-то из несведущих людей, готовивших съезд, допустил ошибку. При открытии заседания $\Lambda$. И. Вербицкая исправит ее», - подумал я.

Но этого не случилось. Ректоры выступали один за другим. Внимания на эту нелепость никто не обратил. Аа и говорили все о самых разных проблемах высшего образования, но не о воспитании.

Тогда я написал $\Lambda$. И. Вербицкой записку, прочитав которую, она тут же сообщила сидевшим в зале 150 ректорам, что мое замечание правильное, это, конечно, ошибка.

Как, однако, такое могло случиться на педагогическом собрании такого высочайшего уровня? Аело тут не в том, что есть ученые, считающие, будто образование и воспитание - вещи разные. Проблема заключалась совсем в другом: в самом начале постсоветского периода, когда шла оголтелая борьба «демократов» со всем советским и коммунистическим, из закона «Об образовании в РФ» (1992 г.) выкинули и воспитание, поскольку для нового, рыночного общества надобно было создавать «нового человека» и перестраивать человека «старого», воспитанного в духе коммунистической идеологии. Это все вполне понятно. Но почему вместе с «коммунистическим духом» изъяли неотъемлемую составляющую часть образования - воспитание, никто до сих пор объяснить не может. Как никто не сказал обществу, почему и в новом законе «Об образовании в Российской Федерации», принятом через 20 лет, в декабре 2012 г., из 131 статьи нет ни одной о воспитании, хотя понятие это в глоссарии присутствует и слово «воспитание» в разных статьях встречается в тексте закона.

Говорить о том, что воспитание в человеческом обществе присутствует с древнейших времен, что оно эволюционирует вместе с развитием общества и в разные времена в разных странах выглядит по-разному, нет никакой нужды, ибо это общеизвестно. Как известны и имена выдающихся педагогов, в том числе российских и советских, внесших вклад в разработку теории и методов воспитания. Прогресс в воспитании связан с общественным прогрессом в целом. Хорошо обученный, но плохо воспитанный человек может быть более вреден, чем полезен. Воспитание - 
корень всему: и добру, и злу. Как можно было это не понимать тем, кто, уничтожив СССР, начал перестраивать «старого» человека и образовывать человека «нового» и «новую» Россию?

Сразу же после того, как из закона «Об образовании» в 1992 г. изъяли воспитание, я, тогда еще директор Научно-исследовательского центра при Институте молодежи, начал выступать за то, чтобы эта фундаментальная ошибка была исправлена. Под моим научным руководством и при моем авторском участии по этой теме были подготовлены Аоклад «О проблемах воспитания в России» и Концепция воспитания жизнеспособных поколений. Комитет РФ по делам молодежи представил этот Аоклад на очное заседание Правительства России, но по предложению министра обороны П. С. Грачева и председателя Комитета по образованию В.Г. Кинелева, а также первого заместителя Председателя Правительства РФ О. Н. Сосковца доклад был объявлен очернительским и снят с обсуждения. Его рассылка в региональные комитеты по делам молодежи была запрещена.

Затем у меня были беседы с тогдашним министром образования РФ В. М. Филипповым. Воспитание на некоторое время реабилитировали, оно появилось в числе аккредитационных показателей вузов, но через пару лет снова исчезло. После этого мы вновь посылали записки в Госдуму, Совет Федерации, в Правительство РФ, публиковали статьи в прессе, выступали на съезде ректоров России. В декабре 2012 г. у меня состоялся краткий разговор с Президентом РФ В. В. Путиным. Затем снова встречался с высокопоставленными чиновниками.

Квинтәссенция всех моих разговоров и письменных документов была (да пока и остается!) краткой: в России нет закона об образовании, существует лишь «Закон об обучении». И это стратегический просчет, который дорого обойдется обществу.

Говорю об этом для того, чтобы подчеркнуть, что поворот к воспитанию, который начал происходить, наконец, в 2016 г., имеет долгую историю.

29 мая 2015 г. Председатель Правительства РФ А. А. Медведев своим распоряжением утвердил Стратегию развития воспитания в Российской Федерации на период до 2025 года (Распоряжение Правительства ... , 2015: Электронный ресурс). В документе подчеркивается, что воспитание является неотъемлемой частью образования, взаимосвязанной с обучением. Воспитание рассматривается как стратегический общенациональный приоритет, требующий консолидации усилий различных институтов гражданского общества и ведомств на федеральном, региональном и муниципальном уровнях.

Что случилось с нашей властью? Не исключаю, что ее серьезно поднапугала ситуация на Украине, где на основе идеологии «украинства», которая, как считают ученые-специалисты, является более радикальной, чем нацизм или фашизм, целенаправленно воспитано уже не одно поколение молодежи, значительная часть которой открыто заявляет в адрес России и русским: «Мы не братья вам и никогда ими не будем». Под боком у России возникло враждебное ей государство с молодыми гражданами, многие из которых никогда не откажутся от бандеровщины, готовы хоть сегодня воевать с Россией и русскими.

4 сентября 2015 г. на заседании Совета Министерства образования и науки РФ по делам молодежи обсужден вопрос о разработке Стандарта по организации 
воспитательной работы в образовательных организациях высшего образования. 18 февраля 2016 г. документ под названием «Стандарт организации воспитательной деятельности образовательных организаций высшего образования» был направлен в учебные заведения.

Наш университет постоянно отслеживает процессы, которые происходят в студенческой среде, реагирует на них.

Весной 2016 г. в МосГУ проведено 15-е по счету исследование «Учебно-воспитательный процесс в оценках студентов». Опрос в очередной раз показал, что в молодежной среде сохраняется весьма критическое отношение к своему поколению, его нравственным качествам. Как и в прошлые годы, студенты на первое место ставят лень - 58,6\%, эгоизм - 42,3\%, безответственность - 37\%. Аоброту отметили всего 10,7\%, ответственность - 5,8\%, честность - 6,3\%, совестливость - $1,9 \%$ опрошенных. Однако при ответе на вопрос: «Какие качества Вы цените в других людях?» - оценка такова: «честность» - 43,4\%, «доброта»$30,7 \%$, «ответственность» - 19,7\%. Аучшей перспективой для себя после получения университетского диплома $18,1 \%$ опрошенных студентов считают обучение за рубежом, а 18,0\% перспективу связывают с постоянной работой за рубежом, т. е. готовы покинуть Родину.

В эти цифры не хочется верить, но наши опросы год за годом повторяют их с небольшими отклонениями. Ну ладно: каждый пятый молодой человек хотел бы получить расхваленное американское, английское или канадское образование, а потом... Вернуться в Россию? Какая-то часть, наверное, так и думает. Как велика эта часть? Мы не знаем. Но часть (какая?), вероятнее всего, надеется остаться в этой стране. А еще $18 \%$ говорят об этом со всей ответственностью. Выходит, и это по самой малой мерке, что каждый пятый, а то и четвертый выпускник вуза готов расстаться с Родиной. Этого, по многим обстоятельствам, конечно, не случится. Но для нас важны настроения, намерения, «привязанность» молодых людей к своей Родине. На мой взгляд, эта ситуация выглядит удручающе, драматично. В чем дело?

«Перестройщики» соблазнили тогдашнюю, «перестроечную» молодежь, бушевавшую на митингах, демонстрациях, «свободой», «демократией», «правами человека», «индивидуальными возможностями», «сытой и комфортной жизнью» и прочими «пряниками». И те двинулись в нужную для заговорщиков и предателей своей страны сторону заокеанских благодетелей от «советского кнута» от чувства долга, от призыва «прежде думай о Родине, а потом о себе» и ему подобных. «Перестроились». Повзрослели с 1991 г. на 25 лет. Перестроившись, кое-кто неплохо устроился. Кое-кто даже отлично. Но «кое-кто». А сотни миллионов молодых людей, некогда сплоченных общей для всех мечтой о светлом будущем, которое приближалось к ним не так скоро, как хотелось, но все-таки приближалось, - бесплатными квартирами, бесплатным образованием, бесплатным здравоохранением, гарантированной работой, гарантированной пенсией, гарантированной безопасностью на улице хоть днем, хоть ночью?.. Многое, что имели, не ценили. А теперь, кто знает, что это было реальностью? Те, кто родился в расчудесные рыночные времена, не верят, будто такое возможно. Они верят лишь в то, что тогда были одни только репрессии, гулаги, психушки и пустые полки в магазинах. 
Однако речь сейчас не об истории, а о настоящем и будущем. Часто говорят, будто ныне существуют две России - богатая и бедная, даже нищая. Это, конечно, так. Только все обстоит еще хуже: страна расколота на многие части, а общество рассыпано на мелкие фрагменты, атомизировано. Наши бессменные враги Запад во главе с США вдолбили в сознание российского народа, да и всего человечества идеи о конце истории, конце идеологии. Можно сказать даже так: о конце историй всех государств, кроме США, о конце всех идеологий, кроме идеологии либерализма, о конце права суверенных государств самим управлять своими делами, кроме права США управлять всем миром.

Россия сопротивляется этим импортным интеллектуальным «открытиям», как ни одна другая страна в мире. В этом огромная заслуга В. В. Путина как Президента. Он и кое-кто из его искренних соратников видят и понимают, что холодная война полыхает уже вовсю, что она в любой момент может сорваться в войну «горячую», более того - ядерную. Одно не понятно мне: видит ли он, как велика уже и нарастает с каждым годом в России «пятая колонна» и что этому процессу надо поставить жесткий предел. Самый жесткий. И чем скорее, тем дучше.

Вот и подошли мы снова к проблеме образования и воспитания.

В ст. 13 Конституции РФ говорится: «1. В России признается идеологическое многообразие. 2. Никакая идеология не может устанавливаться в качестве государственной или обязательной» (Конституция .... : Электронный ресурс). Но разве не понятно, что в России властвует идеология либерализма? Аюбому образованному человеку ясно. Но идеологии создаются для масс, Аля низов, не способных разобраться в запутанности словесных ухищрений, терминов, понятий, определений. Надобно, чтобы потребитель идеологии был соблазнен и очарован десятком словосочетаний, смог проглотить, переварить их в своей голове и запомнить навсегда как «Отче наш». Вот эти желанные слова, сулящие исполнение всех человеческих желаний: свобода, демократия, рыночная экономика, свободная конкуренция, право человека, частная собственность... И т. п. Аля обывательского мышления этого более чем достаточно. Он нажимает на кнопку «иллюзии» - и вот он уже, как гласит русская пословица, «сыт, пьян и нос в табаке».

Идеология - это способ оболванивания миллионных масс. Парадокс в том, что без идеологии общество долго существовать не может. Утопия возвышает массы, она движет их вперед, как недостижимая, но великая цель, на пути достижения которой общество развивается, добивается, казалось бы, немыслимых успехов, одерживает невиданные победы. Эта истина, на мой взгляд, справедлива как для либерализма, так и для коммунизма. И та, и другая идеологии доказали свою мощь. Аругое дело, что в ходе смертельной схватки между собой одна из них (коммунизм) убита, хотя можно сказать - очень тяжело ранена, ибо была предана, другая (либерализм) - приговорена к скорой гибели в 1992 г. в Рио-де-Жанейро, и мы наблюдаем ее первые конвульсии в стремлении выжить любым путем за счет покорения всего мира и овладения его ресурсами.

Страшно мешает ей в этом Россия - огромный осколок СССР. Потому и разгорается холодная война. А российское общество, во всяком случае, на мой взгляд, большинство населения, живет так, будто в России, как сказано в ее Конституции, никакой господствующей идеологии и на самом деле не существует. А то, что телевидение и все остальные СМИ - это органы либеральной пропаган- 
ды, воспринимается с юмором: они же нас развлекают! Ну да - развлекают. Отвлекают. Увлекают... Там, в редакциях и телебашнях, сидят беспринципные прохвосты, интеллектуальные пигмеи, способные, правда, придумать что-нибудь такое пошленькое, подленькое, но простительно смешное...

А война... так ведь пока еще только холодная. «Горячая» далеко от нас. Коварство войны нового типа в том и состоит, что она не воспринимается как война. Более того, послушать дипломатов из разного рода ток-шоу, так эта война - всего лишь способ избежать настоящей войны.

Почему так происходит? Однажды я написал на эту тему большую статью под названием «Образование в целях оглупления» (Ильинский, 2011: 695-734). Попробуйте отыскать Аоклад Всемирного банка «Образование России в переходный период», подготовленный по заказу российского правительства в 1994 г., почитайте его - и вы поймете, почему «реформы» образования в России идут уже 22 года, а оно лучше не становится, если не говорить о трех-четырех последних годах...

Воспитание - процесс целенаправленный. Но какова же его цель? Как говорил еще Сенека, «для корабля, порт назначения которого неизвестен, нет попутного ветра».

Главная проблема, на мой взгляд, состоит в том, что у России нет не только государственной идеологии, но и национальной идеи. Сегодня власти пытаются утвердить в качестве национальной идеи патриотизм. Я - категорически за любовь к России. Мы, безусловно, должны воспитывать патриотов. Но патриотизм вряд ли может стать такой идеей. По многим причинам. Слишком много олигархов и других богатеев, в честности которых можно сомневаться. Коррупция безмерна и бессмертна. Бедных и нищих все больше.

Гордиться по-настоящему своим народом и своей страной можно лишь тогда, когда в ней нет причин стыдиться ни за одно из ее сословий; когда народ точно знает, что если министр развалил важнейшую отрасль, а его подруга наворовала миллиарды, то они непременно окажутся за решеткой; что человек, которого ненавидит вся страна, не получит права «реформировать» ее энергосистему, возглавлять ведомство новейших технологий...

Остановлюсь: всем все известно.

Мне есть за что любить свою страну, а надо будет - и умереть за нее. Потому что у меня есть хоть и очень нелегкое, но достойное человека прошлое, которым я обязан СССР - России. А тем, кто только начинает свою взрослую жизнь?.. Им как быть? Есть у них предки, есть славная история. Но к этому чувству любви к Родине надо добавить еще нечто в настоящем, чем можно гордиться перед всем миром. Аа, есть в стране партия «Единая Россия». И она немало значит, пока есть Президент РФ В. В. Путин...

Нет национальной идеи, которая стягивала бы народ в единое целое, пока нет.

В результате в стране начинается местечковое творчество.

Первый пример. В этом учебном году во всех школах Краснодарского края появятся «казачьи школы». Губернатор края Кондратьев считает, что как минимум с семи лет ребенок должен понимать, что он казак, поэтому образование должно быть казачьим. На Кубани уже 1700 казачьих классов, в которых учится 40 тыс. детей. Первоклашки дают торжественную клятву верности Кубани (не 
России!) и казачеству. Перед уроками «казачата» совершают молебен: казак без веры - не казак.

Пример второй. Российская академия образования направила на экспертизу в ряд организаций проект курса «Православная культура» для общеобразовательной средней школы (с первого по одиннадцатый класс). Главным поборником нового курса выступает Патриарх Московский и всея Руси Кирилл, неоднократно заявлявший о намерении влиять на образовательную политику государства. Он предлагает расширить курс основ религиозных культур и светской этики. Напомним, РПЦ предложила преподавать этот курс не только в четвертых классах, как происходит сегодня, но и во втором, третьем, пятом - девятом классах.

Сейчас изучение «Основ религиозных культур и светской этики» (ОРКСЭ) в четвертом классе дает родителям право выбрать один из предлагаемых модулей предмета: светская этика, православие, мировые религиозные культуры, ислам, буддизм или иудаизм. Если новый проект будет принят, то изучение курса «Православная культура» станет обязательным предметом для всех школьников на весь период учебы.

Представители других конфессий призывают авторов курса не раскачивать лодку, так как предлагаемая программа может спровоцировать противостояние в некоторых регионах.

Пример третий, говорящий о том, что лодка уже качается. В Казани задумали приобщить к шариату детсады и школы, провели опрос в образовательных организациях, не хотят ли обучающиеся перейти на питание, соответствующее исламу. Эксперименты уже проведены. Заметим: в России 25 млн мусульман.

Между тем согласно Конституции (ст. 14) Россия - светское государство. Значит, и все институты в нем тоже светские, включая школы, колледжи, гимназии и вузы.

Новации, которыми заняты некоторые регионы, да и Минобрнауки, где разрабатывается проект примерной программы по курсу «Православная культура», могут привести к таким потрясениям всей системы образования и российского общества, что многие его социальные и политические проблемы покажутся мелочью.

Власть и общество должны отдавать себе полный отчет в том, что система образования, социальные и гуманитарные науки, культуры - главные инструменты воспроизводства и сохранения единства и цельности общества, что они играют главную роль в определении национальной идентичности и индивидуальности, которые реально дают нам шанс занять достойное место в современном мире.

Необходимо держать курс на воспитание у молодых качеств жизнеспособности, развитие тех добродетелей, которые помогут им найти и сохранить себя как личность и индивидуальность в современном обществе (не буду его характеризовать) и в то же время - не оторваться от людей ближнего окружения, от общества, от Родины. Не стану сейчас распространяться на эту сложную научную тему. Ее надо обсуждать в вузах на кафедральных, факультетских и университетских круглых столах, научных конференциях.

Скажу одно: это задача педагогическая, и это задача самих обучающихся, студентов. Молодым людям надо внушать мысль о необходимости планомерного саморазвития, самовоспитания. 
Сегодня информационно-культурное пространство, которое окружает студента, насыщено пропагандой ценностей потребительского общества, где агрессия и насилие выступают как законные средства достижения целей. Героем нашего времени выставляется негативный лидер. В ранжире людей, на которых стоит равняться, появились бессердечные прагматики, дельцы, кидалы, словом те, кто из воздуха делает деньги, становится преуспевающим. В сознание подрастающего поколения усиленно насаждается образ американского киногероя.

$\Lambda$ ет 15 назад, глядя на студенческую массу университета, ее пристрастия и поведение, я с трудом вычленял из нее несколько, как я называл тогда этих молодых людей, «поколенческих единиц». Они вызывали у меня чувство восхищения своей тягой к знаниям, способностями, целеустремленностью и огромным, совсем не юношеским трудолюбием.

Недавно в одном из разговоров на эту тему с проректором по воспитательной работе тот заметил, что теперь в университете таких выдающихся «единиц» не менее 200 на несколько тысяч.

Много это или мало? Аостаточно. Очень много духовно и нравственно одаренных, талантливых от природы детей и быть не может. Если с ними грамотно работать, то эти «немногие» помогут вузам и обществу решить многие задачи и в успеваемости, и в воспитании, и в оздоровлении всей образовательной среды, а также многие другие. Они станут образцом Аля подражания для молодых

Педагогам известно, что еще несколько веков назад французский философ и писатель Ж.-Ж. Руссо в своей книге «Эмиль, или О воспитании» подверг критике существовавшую практику организованного воспитания, предложил проект воспитания нового человека и теорию свободного воспитания. По его мнению, педагог должен терпеливо следить, как воздействуют на воспитуемого три главных воспитателя: природа, люди, общество, лишь устраняя их вредные влияния. Наилучшее воспитание, полагал Руссо, - это прежде всего накопление собственного жизненного опыта, который приобретается к 25 годам (Руссо, 1912).

Но есть ли сегодня в мире хоть одна страна, в которой «свободное воспитание» реализуется именно в таком виде? Я таковых не знаю. Что США, что Европа имитируют «демократию», а некоторые образовательные организации - «свободное воспитание».

Сегодня мало признавать, что холодная война идет. Надо понять, что Россия находится в предвоенном состоянии самой настоящей «горячей» войны, которая может сорваться в ядерную. И что к этому надо готовить не только оружие, но и людей, особенно молодых. Гитлеровский нацизм с его безмозглыми «оловянными» солдатами был повержен Советским Союзом благодаря массовому героизму на фронте и в тылу. Именно массовым! А массовый героизм, в свою очередь, был результатом общественного, организованного воспитания готовности к войне, начиная с детского, школьного возраста. Существовала жесткая система воспитания, и нынешняя Россия вновь нуждается в ее хотя бы частичном восстановлении.

\section{3. ОБ ИССАЕАОВАТЕАЬСКОМ ОБРАЗОВАНИИ}

Есть направления вузовской деятельности, где затормозился не только наш университет, но и подавляющая часть российского образования. На мой взгляд, это развитие исследовательского образования. 
Организация исследовательского образования должна стать основной формой университетской, а значит, и школьной подготовки. Это главная стратегическая задача, которую должны решать наше общество и государство.

Я думаю, здесь надо говорить далеко не обо всех обучающихся, а об определенных группах школьников и студентов, перспективных с точки зрения работы с современным знанием. Постановка исследовательского обучения на первом этапе могла бы предполагать (1) разработку особых, исследовательских программ обучения по профилированным предметам, затрагивающим и содержание, и методы, и образовательную среду; (2) формирование групп перспективных обучающихся в школах и вузах; (3) создание материально-технической базы исследовательского творчества; (4) включение согласованных программ исследовательского обучения в учебный процесс разных ступеней общего и высшего образования.

Финансовые ресурсы и госстандарты сами по себе не обеспечат самого главного - понимания того, кого, чему и как следует учить. Обучаемые должны вырастать настоящими людьми, способными и готовыми трудиться не только ради собственных интересов, но также и на общее благо. Именно об этом я писал в книге «Образовательная революция» еще в 2002 г., утверждая, что парадигма образования «ЗУН» полностью исчерпала себя и ее должна заменить новая парадигма - «ЗПУ »: знания, понимание, умения (Ильинский, 2002). Никакие госстандарты, построенные на основе действующей парадигмы, не помогут нам превратить наше больное общество в здоровый социальный организм. Аля этого требуется значительно большее. Чтобы считать современного выпускника школы или вуза образованным, абсолютно недостаточна его способность давать правильные ответы по каждой из областей знаний, которые были признаны целесообразными для изучения.

Абсолютно недостаточны и так называемые общая и специальная компетентности в контекстах стандартизированных учебных процедур. Систему российского образования и российское общество спасет только подготовка значительной части выпускников школ, среднего профессионального и высшего образования, способных понимать окружающий мир и происходящее в нем, способных творить.

Нынешнее соперничество России с Западом помимо геоподитического и оборонного фронтов распространяется также на сферы образовательного, научного и технического прогресса. Может ли Россия тягаться ныне с Западом в этих областях? Аостаточно ли у нас для этого интеллектуальных ресурсов? Смогут ли наши школы и вузы дать своим ученикам и студентам необходимые знания в области как точных наук и математики, так и гуманитарных? Вот вопросы, которые должны волновать наше общество и государство.

Россия дореволюционная и Советский Союз уже дважды доказывали миру: мы можем быть первыми и лучшими, если хотим этого.

Пример первый. Во второй половине XIX в. в России в стенах Императорского московского технического училища (ИМТУ, ныне - МГТУ им. Н. Э. Баумана) сформировался «русский метод подготовки инженеров», который особым образом сочетал теорию и практику при обучении «искусных мастеров... знающих новейшие улучшения... и способных к распространению оных» (Научные школы ... , 1995: 3). В 1873 г. на Всемирной выставке в Вене «русский метод», представлен- 
ный ИМТУ, был удостоен Большой золотой медали. «За Россией признан полный успех в решении столь важной задачи технического образования, - писал президент (1870-1878 гг.) Массачусетского технологического института Аж. Рункль, в Америке после этого никакая иная система не будет употребляться» (там же: 6-7). Сегодня Массачусетский институт - один из лучших исследовательских университетов в мире, а принципы "русского метода» подготовки инженеров составляют в нем основу современного исследовательского образования.

Пример второй. Запуск 4 октября 1957 г. первого советского искусственного спутника Земли стимулировал работу по совершенствованию образования в США, которая проходила под влиянием когнитивной революции в психологии. В этот день президент $A$. Эйзенхауэр в обращении к американскому народу сказал: «Наши школы сейчас важнее наших радиолокационных станций; школы таят в себе бо́льшую силу, чем энергия атома». Тогда еще конгрессмен Аж. Кеннеди предупреждал американцев: «Не будет преувеличением сказать, что битва, которую мы ведем сейчас, может быть выиграна или проиграна в школьных классах Америки».

Что нужно сделать для этого? Не так уж много, но и немало: декларации о приоритетности образования перевести в плоскость особого политического внимания развития креативного, исследовательского образования от дошкольного, школьного, среднего профессионального и до высшего образования. Надо поставить образование на службу национальному могуществу и благосостоянию. Многократно усилить централизованное (т. е. государственное) финансирование, принудить крупный бизнес и олигархическое сообщество к вложению значительных средств в образование вообще, но особенно в образование исследовательское, поддержку талантливой молодежи. Еще раз скажу: олигархов надо принудить к этому законом. Аовольно бы уж им высасывать последние соки у бедного и нищего населения, на налоги которого существует в основном российское образование, да еще и пенять на его низкое качество.

Нельзя не видеть, что концепция «образование через научные исследования» определяет ближайшие перспективы в сфере реформ образования на Западе. При этом главными здесь становятся вопросы педагогики и психологии творчества: как организовать образование, чтобы получить ту образовательную среду, в которой обучающиеся приобрели бы навыки ведения исследовательской работы. Имеются в виду также педагогические приемы, выполнение творческих учебных задач, исследовательский метод обучения, особая форма наставничества при взаимодействии учитель - ученик, которая способна реализовать «познавательное обучение». Так происходит на Западе становление исследовательского образования в качестве отдельной части образовательной системы общества, развивающегося в парадигме общества знаний. Вот этому надо учиться у Запада и опережать его, а не следовать рекомендациям Всемирного банка и прочим советам «по применению дохлой кошки» из прошлых веков.

Мы должны воспитывать (развивать) у студентов вкус и способности к исследовательской деятельности, формировать тип научного мышления. Согласно ФГОСам, мы даем студентам фиксированный набор знаний и способов (умений и навыков) для решения известных и повторяющихся задач. Между тем обучение, связанное с исследовательской деятельностью (исследовательское образова- 
ние), должно готовить молодых людей к быстро меняющемуся и усложняющемуся миру и практической деятельности в той или иной сфере. Этот процесс должен начинаться в школе, продолжаться в вузе и дальнейшей профессиональной деятельности.

В этом случае определяющее значение приобретает вопрос о творческих отношениях и взаимодействии преподавателей и студентов. Только тот, кто исследует сам, может действительно обучать и приобщать обучаемого к творчеству, научному мышлению. Аругие преподают лишь нечто устоявшееся, дидактически упорядоченное. Аля данной деятельности также нужны свои, и немалые, способности, свой талант, но научный тип мышления сформировать у студента такие преподаватели не в силах. Об исследовательском образовании тут не может быть и речи. Никакое общество знаний люди, не одаренные научно, не создадут. Перед нами во весь рост стоит задача усилить органическую связь исследования и преподавания.

Надо в полной мере осознать, что участие в исследованиях - это неотъемлемый элемент учебного процесса, если мы говорим о высококачественном образовании, тем более университетском.

Не стану говорить об идеях опережающего образования, т. е. о подготовке работников знаний к той работе, которая еще не существует; о воспитании талантов для общества знаний, экономики знаний, о переподготовке в течение всей жизни (непрерывное образование) и пр. Кое-что из всего этого мы уже можем наблюдать в отдельных университетах и в жизни.

Во всяком случае, следует всерьез подумать о создании при некоторых университетских кафедрах и факультетах научных лабораторий. В перспективе учебный процесс должен стать неотделимым от исследовательской деятельности. Исследования должны стать своего рода методикой обучения. Тем самым весь учебный процесс, начиная со школьной скамьи (повторяюсь), станет формировать познавательную функцию мышления обучаемого.

\section{4. О СООТНОШЕНИИ ТОЧНЫХ И ЕСТЕСТВЕННЫХ НАУК \\ С НАУКАМИ ОБЩЕСТВЕННЫМИ И ГУМАНИТАРНЫМИ}

«Что-то физики в почете, что-то лирики в загоне», - писал в начале 1960-х годов Б. Слуцкий. По тем временам эту ситуацию можно было как-то объяснить: в сталинские годы - бурная индустриализация, затем - Великая Отечественная война, а за нею - холодная война, гонка вооружений. Аа и просто СССР имел огромную по масштабам и чрезвычайно многообразную промышленность.

А сейчас-то почему министерство образования все пост- «перестроечные» годы возглавляли доктора физико-математических наук? Многое, конечно, объяснимо: глобализация, информационно-телекоммуникационная революция, беспрецедентно быстрый рост роли и значения высоких технологий... Можно подумать, что технологический императив обрел статус аксиомы, а экономический рост стал своего рода мировой религией. Можно решить, что в споре физиков и лириков последние бесповоротно и окончательно повержены: педвузы закрывают, на факультеты психологии абитуриенты не идут даже на бюджетные места и т. А.

Аа, в 1990-е годы общественные и гуманитарные науки поначалу получили небывалый рост, немыслимый в годы советской власти. Практически все почти 500 не- 
государственных вузов, возникших в ту пору, занимались именно этими науками. Но, по сути дела, все только начиналось: качество образования в них было в основном крайне низкое. Была объявлена борьба за его повышение. И вот теперь, после четырех мониторингов әффективности, начиная с 2013 г. количество этих вузов в России сократилось с 490 до 90 «эффективных». В госвузах, где социально-гуманитарные факультеты являются непрофильными, их тоже закрывают. Социальногуманитарные науки снова в загоне?..

К чему я все это говорю? К тому, что в «правильной системе образования» точные и естественные науки, с одной стороны, и общественные и гуманитарные с другой, должны составлять равновеликие и взаимодополняющие подсистемы. Одна без другой рано или поздно начнет деградировать. Мне кажется, что правильное соотношение между этими подсистемами уже утрачено, что те, кто руководил образованием все эти годы, да и руководители государства, законодательные органы этого не замечают или не хотят замечать. Тем более олигархат с примкнувшими к нему бизнесменами, для которых Россия, как говаривал известный тюремный сиделец, а ныне беглый олигарх Ходорковский, - «это пространство для свободной охоты». Этим людям на такого рода проблемы, попросту говоря, наплевать.

Но те, для кого Россия - родина, те, кто хочет видеть ее жизнеспособной, благополучной и сильной, понимают, что в основе любой великой державы (повторюсь!) должен лежать более или менее внятно сформулированный идеал, из которого вытекают миссия нации и государства, их главные цели и взгляд на место в мировом сообществе. Идеал связывает общество и государство в единое целое. Иначе нация, государство и общество рано или поздно рассыпаются, атомизируются и погибают.

В известной степени (не говоря о внешнем факторе) из-за эрозии своей идеологии был уничтожен СССР. Советская система, а точнее ее высшее руководство, не допускало существования в научном сообществе крупных философов, политологов, социологов - ученых-мыслителей, чьи идеи корректировали бы существовавшую идеологию, противодействовали бы ее атрофии.

Нынешние попытки отодвинуть социальные и гуманитарные науки на второй план, загнать их еще дальше в тупик таят для России большую опасность. «Технологическая парадигма» с ее очевидными успехами, призывы «построить благополучную Россию, где будет комфортно жить» - верить во все это довольно наивно: ведь это идеал все того же общества потребления, который на наших глазах уже достаточно опростоволосился: он ведет к конфликтам и войнам, ибо «всем всего не хватит».

Скажу еще раз: на мой взгляд, Россия не имеет более или менее внятного идеала, который определял бы всем понятный путь ее движения в будущее. В 1990 -е годы власти пытались вместе с учеными создать некий новый вариант национальной идеи. Но из этого ничего не вышло: любой национальный идеал возникает на основе уже существующих философских, политических или религиозных Аоктрин. Их не было в те времена, нет и сейчас. Общество остро нуждается в прорывных идеях, базирующихся на фундаментальных социальных и гуманитарных исследованиях. «Чтобы попасть в рай, необходимо тщательно изучить дорогу, ведущую в ад», - предупреждал мудрый Н. Макиавелли. Говорю әто к тому, что России не 
следовало прежде, тем более сейчас бездумно принимать к реализации затасканные западные (особенно американские) идеи и модели образа жизни, ибо мы воочию наблюдаем, как строят они ад в любой точке мира, где «вдруг» обнаруживаются их национальные интересы...

\section{5. КРИЗИС ПОНИМАНИЯ: \\ К НОВОЙ ПАРААИГМЕ ОБРАЗОВАНИЯ}

Если оставить в стороне грандиозные успехи и фантастические достижения XX в., которые общеизвестны и несомненны, то второй составляющей совокупного итога этого века является узел острейших проблем. Многие из них уже давно утратили национальную и даже региональную окраску и получили название глобальных. Эти проблемы хорошо известны, как известно и то, что при дальнейшем обострении они угрожают человечеству катастрофическими последствиями вплоть Ао его гибели.

Есть ученые, которые полагают, что это апокалиптический взгляд на будущее и он неуместен. Так думал, в частности, видный российский ученый С. П. Капица. По его мнению, основной глобальной проблемой человечества следует считать рост населения, который порождает все остальные, в том числе антропогенные изменения окружающей среды, возможное исчерпание ресурсов, сам факт ускорения развития. В росте численности населения он видел меру развития во всех измерениях (Капица, 1999: 31). На основе собственных расчетов С. П. Капица пришел к выводу, что рост населения планеты в середине XXI в. прекратится, начнется его падение, а вместе с этим «уменьшатся, если не исчезнут, причины больших войн» (там же: 184). Иначе говоря, острота глобальных проблем резко уменьшится, а значит, отпадет и вероятность самоуничтожения человечества.

Споры идут, а положение дел в мире между тем не улучшается, а обвально ухудшается. Это со всей очевидностью подтвердила, в частности, проходившая в 2002 г. в Йоханнесбурге под эгидой ООН Всемирная встреча по проблеме устойчивого развития. Многие назвали этот саммит «Рио минус $10 »$, имея в виду, что 10 лет, прошедших после известной конференции 1992 г. «Окружающая среда и развитие» в Рио-де-Жанейро, на которой лидеры 179 стран признали, что действующая парадигма развития человечества полностью исчерпала себя и необходимо ускоренно переходить на новый путь развития, - эти 10 лет мало что изменили, жизнь продолжала идти по схеме «как было», десятилетие потеряно, и новая встреча по тому же самому поводу не имела успеха.

Почему же человечество, знающее о грозящей ему смертельной опасности, словно околдованное все быстрее мчится навстречу гибели? Аело в том, на мой взгляд, что XX в. оставил нам в наследство еще одну глобальную проблему - неосознанность происходящего, иначе говоря - кризис понимания. По-моему, это самая главная из всех глобальных проблем - проблема № 1. Ибо, как известно, все, что происходит в социуме, - как плохое, так и хорошее - сначала возникает в человеческой голове.

Аавно замечено, что проблема понимания встает именно тогда, когда разрушается реальное понимание происходящего (действительности), а случается это в ситуациях научных революций, смены идеологических парадигм, угрозы полной не- 
возможности использовать имеющийся человеческий опыт и т. п. (см., напр.: Загадка человеческого ... , 1991: 5, 17, 26 и др.). Иначе говоря, проблема понимания носит прежде всего практический характер. Понимание служит созиданию и в этом смысле является условием выживания человечества. Научные дискуссии по проблеме понимания продолжаются многие столетия, но всякий раз, когда непонимание происходящего в обществе достигает критической точки, возникает потребность прорыва в постижении действительных смыслов социальных явлений и событий не только выдающимися учеными и политиками, но и массами, из которых они рекрутируются.

Если говорить о причинах, которые привели человечество к нынешнему кризису понимания, то они заключаются в том, что темпы, скорость, сложность и масштабы событий и перемен, которые происходили во всех областях общественной жизни на протяжении XX в., особенно во второй его половине, превзошли нашу способность понимания происходящего как на коллективном, так и (тем более) на индивидуальном уровне. Речь не только об обыденном, но и о научном сознании; не только о миллиардах обывателей, но и о тысячах тех, кто стоит во главе государств и правительств, политических и общественных, в том числе международных, организаций, ТНК и т. п., т. е. обо всех, кто участвует в принятии судьбоносных решений.

Сущность кризиса понимания (я говорю о социальных процессах, о гуманитарной сфере), на мой взгляд, определяется в нескольких измерениях.

1. Мы все хуже понимаем происходящее в новейшей истории вследствие нарастания хаоса и абсурда.

2. Мы не понимаем, что мы - не понимаем, и прежде всего потому, что не хотим признать этот факт, не хотим понимать.

3. Мы не понимаем, что́ мы не понимаем. В обществе происходит много такого, что пока находится за пределами понимания.

4. Мы не понимаем, что́ мы должны понять. Нам известны многие вызовы и угрозы будущего. Но нет полного понимания их смертельной опасности, а потому нет предотвращающих ее адекватных действий.

Эти выводы могут показаться парадоксальными и даже абсурдными: ведь XX в. - век научно-технической и информационной революций, век компьютера и Интернета, невероятно увеличивших возможности человека невероятно больше знать и фантастически быстро считать, вычислять и рассчитывать. Мир уже давно говорит, как это было когда-то, не о нехватке, а об избыточности информации. Но именно отсюда и берет свое начало кризис понимания - из избыточности, хаоса информации, в том числе изначально ложной в своей сущности, сознательно создаваемой как искажение, фальсификация, мифологизация истории, насущной действительности и еще неизвестного, но уже умышленно искажаемого будущего, как, например, «столкновение цивилизаций» (С. Хантингтон), «конец истории», «конец последнего человека» (Ф. Фукуяма), «великая шахматная доска» (3. Бжезинский) и т. п. Кто они, эти люди? Ученые? Может быть. Но я не исключаю, что просто умные «генералы» войны за мировое господство страны, в которой они живут и которой преданно служат. Очень выгодная работа: тут тебе и деньги, тут тебе и гарантированная мировая слава. А то, что в мире все происходит именно так, как они «предсказали», объясняется очень просто: их «научные» труды - это 
политические проекты, за которыми стоят национальные интересы «богоизбранной» страны и самые могучие вооруженные силы.

Скорость и темпы нарастания объемов информации о множестве разноплановых и быстро меняющихся, в основном сенсационных, а среди них прежде всего катастрофических и криминальных, событий, как это мы видим на примере России, сеют в душах и умах людей хаос и смятение. Человек все больше лишается внутреннего спокойствия, внутренней тишины и сосредоточенности, без которых невозможна интеллектуальная деятельность - размышления и понимание. Более того, в условиях, когда личностные защитные механизмы не срабатывают, ослабевают импульсы для самостоятельного генерирования новых знаний и самостоятельного поиска существующих смыслов, что и представляет собой процесс понимания. В этой ситуации человек оказывается особенно предрасположенным к внешнему воздействию и восприятию разного рода штампов, клише, стереотипов, мифов, образцов поведения, которые, как мы видим, ему агрессивно навязывают СМИ: телевидение, радио, видео, СD и Интернет. И, конечно же, никуда не исчезающие противники и враги России, для которых она во все века была и остается главным объектом зависти и ненависти. Гитлеры приходят и... приходят. Еще недавно самым страшным явлением казались нацизм и фашизм, оказалось, есть кое-что похуже их - «украинство»...

Тем не менее на обыденном уровне сложилось представление, что мы сегодня очень много знаем, а значит, если не всё, то достаточно многое понимаем. На первый взгляд так оно и есть. Но спросим себя: что мы знаем? Сплошь и рядом мы знаем слова и названия явлений, событий, процессов, но не их содержание, не глубинный смысл, т. е. сущность. В данном случае мы говорим о подмене знания сущности предмета знанием его названия, которое принимается за понимание. На самом деле это иллюзия знания, иллюзия понимания.

Между тем радио и телеэфир, страницы газет и журналов сегодня забиты множеством навязших в зубах, всем уже надоевших слов и выражений - либерализм, рыночная экономика, глобализация, международный терроризм, новый мировой порядок, наступление НАТО на Восток, образование XXI века и другими, которые определяют содержание нашей жизни. Между прочим, это сложные по своему содержанию понятия, в чем их действительный смысл, большинство не понимает, хотя редко кто согласится с этим: «Я имею высшее образование и - не понимаю?! Аа что тут такого сложного, чтобы я не мог понять?»

Вот то же «украинство», выросшее из «братского народа» на наших глазах за четверть века, не распознали до сих пор. «Шо це таке?»- большинство народа, тем более русского, не то чтобы не поняли, даже подумать об этом не хотят. «Аа быть такого не может!»

Понимание - это синоним творчества, это творческий процесс, это огромный труд. Тем более когда речь идет о постижении смысла глобальных явлений и процессов типа тех, которые я только что назвал. Аалеко не все готовы «перетрудиться», чтобы понять то, что не входит в круг их непосредственных служебных обязанностей, не приносит прямой пользы. Каков итог?

Здравомыслящий человек давно понял, что далеко не всякая информация полезна, что «многознание уму не научает». Налицо уже бегство не только от свободы, но и от информации и «лишних знаний». Хаос и абсурд происходящего ведут 
к разрушению целостности личности, уничтожению в человеке человеческого, в частности его стремления познавать и понимать. Бедность и нищенское существование миллионов низводят их до такого состояния, когда жизнь воспринимается как физическое выживание, а спасение видится в том, чтобы не напрягать ум и душу - не видеть, не слышать, не знать, не понимать самому, слепо принимая навязываемую извне точку зрения.

Более 40 лет назад Э. Тоффлер писал о том, что человечество погибнет скорее не от нехватки сырьевых ресурсов и пищи, а от психологической перегрузки. Тогда он имел в виду новую социальную болезнь - шок от будущего (Тоффлер, 1997). И вот оно пришло, это будущее. Многое в мире изменилось, не улучшилось, а ухудшилось. А будущее продолжает наступать: время неостановимо...

Сегодня в России можно смело говорить о шоке от прошлого и будущего, ставшего настоящим, от абсурда происходящего вообще.

Социальный хаос (а значит, хаос в мыслях и душе человека) в мире, особенно в России, с каждым годом нарастает. Ао какой поры это может продолжаться? Сколько хаоса в обществе можно допустить? Ведь психические возможности человека не беспредельны. Сколько хаоса он может вынести? Парадокс состоит не только в том, что на эти вопросы не существует ответа и его никто не ищет. Появились научные теории, которые, если их неточно интерпретировать, чуть неверно понять, могут подтолкнуть мысль к абсолютизации «нестабильности» (неустойчивости), «самоорганизации», «открытости», «случайности», «хаоса», «флуктуаций», «бифуркаций», «диссипативных структур» и т. п. Имею в виду выдающиеся труды нобелевского лауреата И. Пригожина.

Конечно, неустойчивость (нестабильность) далеко не всегда зло, ее нельзя воспринимать лишь негативно. Это не досадная неприятность, подлежащая устранению. Полная устойчивость и равновесность, т. е. полный покой, - это состояние смерти. Только в неустойчивом положении система движется и развивается. Без неустойчивости нет развития. Соблазнительно сказать, что неустойчивость - это и есть развитие.

Но если и в самом деле неустойчивость отождествить с развитием, признав ее тем самым главным свойством всех систем (в данном случае мы говорим о социальных системах), то в мире (и без того предельно хаотичном) хаос воцарится вместо порядка и нам придется забыть о таких понятиях, как «прогноз», «программа», «план», «организация», «контроль», «управление» и т. А. Но тогда общество и государство, вся общественная жизнь распадутся.

Мы должны все же понимать, что случайность не отменяет закономерность. Если мы желаем устранить хаос, упорядочить нашу жизнь, то задача состоит вовсе не в том, чтобы поменять их местами, а в том, чтобы понять закономерность случайности и ее действительную роль в социальном мире. И сколько бы ни восхваляли хаос, ясно, что люди тоскуют по порядку и всегда будут идти к нему, желая понять причины, мешающие им достичь своей цели. Нестабильность не сможет отменить и заменить детерминизм. Они предполагают друг друга, определяются друг через друга.

Когда я слышу призывы «разрушить уходящий в глубокую древность стереотип страха перед хаосом, увидеть красоту и конструктивность хаоса», «понять разрушение как креативный принцип, а страсть к разрушению как творческую 
страсть» (Князева, Курдюмов, 2002: 65), то мне кажется, что научные книжки стали писать наивные люди, не способные увидеть и понять даже то, что происходит за окном их дома, не говоря уж о лежащей в руинах огромной стране; люди, не умеющие управлять даже собой, но тем не менее отчаянно рассуждающие о том, «как управлять, не управляя», «как преодолевать хаос, его не преодолевая» (там же).

«Ничего слишком», - говорили древние. Сегодня, когда мир и мысль находятся в разломе, исследователю и просто мыслящему человеку чрезвычайно необходимы взвешенность суждений, чувство меры в делах.

«Аерзайте понимать!» - призывал когда-то И. Кант. Сегодня надобно сказать по-другому: «Мужайтесь понимать!» Ибо сегодня понимающий человек зачастую сталкивается с такими адскими идеями, такими ужасающими доктринами и мыслями, что от них можно просто свихнуться. Чтобы этого не случилось, одни люди сознательно, другие инстинктивно включают защитный механизм своего организма: утрачивают желание знать и понимать: «меньше знаешь - крепче спишь»; «многие знания - многие печали». Сегодня, чтобы понимать, надо иметь не только неуемное стремление и недюжинный интеллект, но именно мужество и особо крепкую психику. Поэтому задачу понимать происходящее до конца ныне берут на себя совсем немногие, и они выглядят на общем фоне, как правило, людьми ненормальными, производителями страшилок и т. п.

Уместно сказать об одном важном факторе, во многом предопределившем кризис понимания: хорошо налаженное производство и изощренное внедрение в массовое сознание заведомо ложного знания. В новейшие времена древние софисты обрели в лице многих философов, историков, социологов, политологов, писателей и журналистов лучших учеников за всю историю человечества. Такой размах софизма им не снился.

XX в. оставил нам в наследство новую и богатую мифологию, в которой неразличимо сочетаются реальность и вымысел, истина и ложь, сдобренные изрядной порцией паранойи. И это не только национал-социалистический миф крови и мифы сталинской эпохи. Это миф о «невидимой руке рынка», якобы самоорганизующемся әкономическом пространстве, на основе которого вырос рыночный фундаментализм. Это миф о конце истории и бесконечном во времени торжестве идей либерализма. Это миф о благах, которые якобы несет с собой глобализация поамерикански. Это мифы о войне цивилизаций и международном терроризме, первопричиной которого якобы является исключительно исламский экстремизм, но никак не все более нарастающая социальная несправедливость и социальное неравенство между странами и людьми.

Я назвал всего несколько мифов, ибо они составляют несущую конструкцию, на основе которой создаются десятки других мифов и мификов, работающих на главную идею XXI в. - создание Нового мирового порядка.

Разобраться в глубинах многих фундаментальных мифов не так-то просто. На их обоснование работают исследовательские институты, центры, лаборатории, в виде аксиом их вдалбливают молодым в классах и учебных аудиториях, по радио и с экрана телевизора. Мифы окутывают все формы нашей жизнедеятельности. При этом неудовлетворяющие стороны действительности, которые складываются в результате ложных посылов, относятся на счет неизбежных ошибок и из- 
держек практической деятельности. Как можно сомневаться, если так думают и говорят все?

Вот, скажем, один из самых больших по значению, фундаментальный миф o «невидимой руке рынка», который опирается на авторитет А. Смита и в понимании фанатиков рыночной экономики представляет полупародию его взглядов.

Аа, Смит полагал, что общий позитивный результат человеческой деятельности в сфере экономики есть сумма свободных и конструктивных действий отдельных личностей. Эта истина находит свое практическое воплощение в достаточной мере независимо от индивидуальных намерений, воли и поступков, некоторые из которых могут быть ошибочными. Но если большинство действий все же имеет позитивный результат, то и совокупный итог будет иметь положительное значение. Каждый действует по своему разумению, на свой страх и риск, не зная, что и как делают миллионы других хозяйствующих субъектов, а результат положительный, прогресс налицо. Вот в чем заключается «невидимость», «автоматизм» рыночных отношений. Словно Бог направляет мысли и водит руками миллионов людей. Красиво. Эффективно. Что еще надо?

Но дело в том, что А. Смит полагал при этом, что такой способ мироустройства требует от человека не просто естественного (свободного) поведения, но и слеАования должному, которое заключено в правилах общественной морали и нормах закона. «Каждому человеку, пока он не нарушает законов справедливости, писал А. Смит, - предоставляется совершенно свободно преследовать по собственному разумению свои интересы и конкурировать своим трудом и капиталом с трудом и капиталом любого другого лица и целого класса» (Смит, 1962: 497). Таким образом, у «невидимой руки» есть жесткое ограничение: справедливость. Эта моральная категория определяет пределы свободы действий предпринимателя. Общественная мораль - вот что, согласно А. Смиту, должно лежать в основе экономики.

Но что происходило на протяжении столетий и что мы видим сегодня? Идея поставлена с ног на голову. Властвуют своеволие, беспредел, жизнь протекает под лозунгом «только бизнес - соль, остальное - ноль». Российская экономика (и не только) строится вне истины и любви, носит, по сути, антиобщественный характер; предприниматели попирали и беззастенчиво попирают именно законы справедливости. Итог? Мир на грани гибели, но не отказывается от этой философии развития.

Вновь скажу: проблема понимания актуальна ныне, как никогда с тех пор, когда тысячелетия назад, еще в эллинскую эпоху, возникла герменевтика - искусство толкования текстов классической древности, Библии, учение о принципах их интерпретации. Сегодня в кризисе понимания находит свое выражение системный кризис бытия человечества вообще. Продолжать не понимать происходящее значит продолжать погибать. Понять - значит спастись.

Как всегда бывает в тех случаях, когда обозначается та или иная проблема, тут же возникает вопрос: что же делать? как ее решить?

Сверхсложная, адски трудная задача, которая не может быть решена разом, быстро и повсюду. Человека можно принудить повиноваться, но невозможно заставить думать и понимать, если он не захочет этого сам. Тем более человека, которого сегодня, на мой взгляд, сознательно отучают думать и понимать: в ситуа- 
ции дележа собственности и власти думающий и понимающий народ правящей элите совершенно не нужен. Ситуация по своей сути становится все более похожей на ту, которая существовала в древней Спарте, когда около 30 тыс. спартанцев управляли 350 тыс. илотов - рабов и ремесленников.

На мой взгляд, главное условие преодоления кризиса понимания - образовательная революция, смысл которой не столько в совершенствовании форм и методов передачи знаний, в новых образовательных технологиях и механизмах финансирования (как это представляется нынешним реформаторам образования не только в России, но и в других, в том числе ведущих странах мира), сколько в переосмыслении миссии образования, которая видится мне спасительной; в определении новых областей знаний и создании новых учебных дисциплин, дающих знание и понимание смысла вызовов и угроз, следствием которых может быть мировая катастрофа; в расширении предметности обучения (которое сегодня сводится к овладению определенной суммой знаний, навыков и умений) за счет прибавления к этим целям обучения пониманию.

Если мир стал сложней, то человек должен развить свои творческие способности до такой степени, чтобы справиться с этой сложностью, упростить ее. Если скорость и темпы общественного развития возрастают, значит, и человек должен Аумать с большей скоростью и точностью. Если объемы информации нарастают лавинообразно, то и человек должен расширять границы своего интеллекта.

Возможно ли это? Возможно. Аавно доказано, что люди обычно используют не более $10 \%$ возможностей своего мозга, даже когда думают с максимальным напряжением. Не более! Большинство - и того меньше. Как получить доступ к оставшимся 90\% умственного потенциала? Развитию и использованию всех шести типов интеллекта (вербального, визуального, логического, творческого, физического, эмоционального) необходимо учить. Аля меня именно в этом смысле проблема понимания (повторюсь) является прежде всего практической. Пусть ученые продолжают спорить о дефинициях и деталях. Но общественный запрос на разрешение кризиса понимания настолько актуален, что на него необходимо давать немедленный и действенный ответ. Аостигнутый уровень понимания проблемы понимания вполне достаточен для того, чтобы на основе теоретических наработок стало возможно создание специальной учебной дисциплины, методик, учебных пособий, позволяющих обучать новые поколения не только запоминанию знаний, но и отыскиванию скрытых в них смыслов - пониманию.

В чем высший смысл образования, чему надо учить, что надобно непременно не только знать, но и понимать - вот в чем, если говорить предельно кратко, заключается суть кардинального, революционного преобразования образования в XXI в., с помощью которого должно быть столь же серьезно, на основе новой парадигмы преобразовано общество. В 2002 г. вышла моя книга «Образовательная революция», в которой эти вопросы рассматриваются довольно обстоятельно. Сейчас я эту тему только обозначил.

\section{ЗАКАЮЧЕНИЕ}

В августе 2016 г. назначен новый министр образования Ольга Юрьевна Васильева - первая женщина в истории России и первый гуманитарий на этом посту. Я внимательно прочитал подавляющее большинство ее публичных заявлений 
на разных собраниях. Скажу одной фразой - мне они по душе. Ольга Юрьевна рассматривает образование как сложный процесс, в котором огромную роль играет воспитание: «Я считаю, что детей не нужно натаскивать на ЕГЭ во внеурочное время -оно должно быть направлено на воспитание, формирование человека» (цит. по: Конюхова, 2016: Электронный ресурс). Я выступаю за это уже четверть века.

О. Ю. Васильева весьма взвешенно относится к прошлому, в частности к советскому периоду, в том числе к личности Сталина. Я разделяю такой подход: слишком много по этому поводу откровенно наврал Хрущев, но и его многократно переплюнул Яковлев и КО.

Важнейшей темой Ольга Васильева считает вузовское образование. При этом она заявляет: «Перед нами не стоит цель закрывать филиалы, нет плана или количественной сетки по сокращению вузов. Более того, некоторые процессы сейчас приостановлены до принятия решений. Существуют мониторинги и работающие оценки качества работы филиалов, их результаты открыты, и каждый гражданин может посмотреть, какова ситуация» (там же). Также министр говорит: «Мы должны посмотреть, что происходит с ЕГЭ, взять лучшее, отмести то, что не стоит делать, и идти вперед. Я считаю, что детей не нужно натаскивать на ЕГЭ во внеурочное время - оно должно быть направлено на воспитание, формирование человека. Человек - это наша главная задача, и внеурочное время - то самое, когда можно с ребенком говорить и что-то делать, чтобы он вырос гражданином нашей страны» (там же). Ну что тут сказать? Все правильно!

Я надеюсь, что новый министр будет вести курс в сторону правильного соотношения точных и естественных наук с общественными и гуманитарными, в отличие от ее предшественников, будет больше считаться с образовательным сообществом и общественным мнением в целом.

\иберальный экспертный пул возопил о клерикализации школы и превращении Министерства образования в министерство патриотического воспитания, а саму Васильеву причислил к крайним консерваторам, монархистам и сталинистам одновременно.

Не стоит торопиться со столь категоричными прогнозами. Пусть Ольга Юрьевна поработает хотя бы 100 традиционных дней. И если за ее правильными словами последуют такие же правильные дела, я запишусь в ее «партию».

\section{ПРИМЕЧАНИЕ}

1 Комплексное социологическое исследование было разработано и осуществлено Высшей школой современных социальных наук (факультетом) МГУ имени М. В. Аомоносова и Институтом социально-политических исследований Российской академии наук. Кураторы исследования - академик В. А. Садовничий, академик Г. В. Осипов. Руководители проекта - д-р филос. наук, профессор И. Б. Орлова, канд. филос. наук Ф. Э. Шереги. Руководитель полевого этапа - д-р социол. наук, профессор Г. И. Осадчая. Участие в полевом этапе принимали преподаватели и студенты Высшей школы современных социальных наук (факультета) МГУ имени М. В. Аомоносова и сотрудники Института социально-политических исследований РАН (см.: Комплексное социологическое ... : Электронный ресурс). 


\section{СПИСОК АИТЕРАТУРЫ}

Загадка человеческого понимания (1991) : сб. ст. / сост. В. П. Филиппов. М. : Политиздат. $351 \mathrm{c.}$

Ильинский, И. М. (2002) Образовательная революция. М. : ИзА-во Моск. гуманит.-соц. академии. 592 с.

Ильинский, И. М. (2011) Прошлое в настоящем. М. : Изд-во Моск. гуманит. ун-та. 840 с.

Капица, С. П. (1999) Сколько людей жило, живет и будет жить на Земле. Очерк теории роста человечества. М. : Наука. 189 с.

Князева, Е. Н., Курдюмов, С. П. (2002) Основания синергетики. СПб. : Алетейя. 413 с.

Комплексное социологическое исследование: «Современная система высшего образования глазами студентов, аспирантов и профессорско-преподавательского состава МГУ имени М. В. Аомоносова» [Электронный ресурс]// Высшая школа современных социальных наук (факультет) МГУ имени М. В. Аомоносова. URL: http://vshssn.msu.ru/nauka-3/ (дата обращения: 12.06.2016).

Конституция Российской Федерации [Электронный ресурс] // Конституция Российской Федерации. URL: http://www.constitution.ru/10003000/10003000-3.htm (дата обращения: 12.06.2016).

Конюхова, К. (2016) Новый министр образования Ольга Васильева рассказала, что дальше будет с ЕГЭ и вузами [Электронный ресурс]// Комсомольская правда. 24 августа. URL: http://www.kp.ru/daily/26573.4/3588042 (дата обращения: 25.08.2016).

Научные школы Московского государственного технического университета им. Н. Э. Баумана : История развития (1995) / К. С. Колесников ; ред. И. Б. Федоров. М. : ИзА-во МГТУ им. Н. Э. Баумана. 439 с.

Распоряжение Правительства Российской Федерации от 29 мая 2015 г. № 996-р г. Москва «Стратегия развития воспитания в Российской Федерации на период до 2025 года» (2015) [Электронный ресурс] // Российская газета. Федеральный выпуск. № 6693 (122). URL: https://rg.ru/2015/06/08/vospitanie-dok.html (дата обращения: 12.06.2016).

Руссо, Ж.-Ж. (1912) Эмиль, или О воспитании : пер. с фр. СПб. : Изд-во газеты «Школа и жизнь». 491 с.

Смит, А. (1962) Исследование о природе и причинах богатства народов. М. : Изд-во социально-экономической литературы. 655 с.

Тоффлер, Э. (1997) Футурошок : пер. с англ. М. : Аань. 461 с.

Аата поступления: 02.09.2016 2.

\section{ON A “PROPER EDUCATION” FOR RUSSIA IN THE 21ST CENTURY \\ I. M. ILINSKIY \\ (MOSCOW UNIVERSITY FOR THE HUMANITIES)}

The article presents the author's reflections on the topical issues of Russian education and factors that have influenced their development and also can facilitate their resolution.

The author justifies the commitment to the classical method of education (auditorium student - lecturer - seminars - practice, etc.), on which the work at Moscow University for the Humanities (MosUH) is based. The method not only has proved its value over many years, including the age of the reforms in Russian education, but students themselves consider it to be preferable. Nonetheless, MosUH does not discard new forms of electronic education.

The author underscores that education must be considered as a single goal-oriented process of personality development (vospitanie) and training. The recurrence of the issues of personality and attitude development, which has been marked by the adoption of state official documents, has had a complicated history. Nevertheless, even among heads of educational institu- 
tions an understanding of education and personality development as autonomous processes can be found.

The development of research education is also mentioned as a common problem of Russian education. It must be a strategic objective both of the society and the state. It is necessary to speak of not nearly all learners, but of certain groups of school children and students who are promising for the purposes of work with contemporary knowledge. The author argues that the system of Russian education and Russian society can be saved only by training a significant part of school leavers and alumni of colleges and universities who are capable of understanding the world around them and the current situation in it as well as of creating.

The author mentions the existence of equal and complementary subsystems of exact and natural sciences, on the one hand, and of social sciences and the humanities, on the other hand, in a proper system of education. Today, the correct proportion between these subsystems has already been lost. We will not understand the essence of social problems without the development of social and humanities knowledge. The author indicates the unawareness of the current events and the crisis of understanding as other global problems of mankind.

Keywords: proper education; higher education; problem of understanding; Russian education; problem of personality development; issues of Russian education; issues of Russian society; global problems

\section{REFERENCES}

Zagadka chelovecheskogo ponimaniia (1991), comp. V. P. Filippov. Moscow, Politizdat. 351 p. (In Russ.).

Il'inskii, I. M. (2002) Obrazovatel'naia revoliutsiia. Moscow, Mosk. gumanit.-sots. Academia Publ. 592 p. (In Russ.).

Il'inskii, I. M. (2011) Proshloe v nastoiashchem. Moscow, Mosk. gumanit. un-t Publ. 840 p. (In Russ.).

Kapitsa, S. P. (1999) Skol'ko liudei zhilo, zhivet i budet zhit' na Zemle. Ocherk teorii rosta chelovechestva. Moscow, Nauka. 189 p. (In Russ.).

Kniazeva, E. N. and Kurdiumov, S. P. (2002) Osnovaniia sinergetiki. St. Petersburg, Aleteiia. 413 p. (In Russ.).

Kompleksnoe sotsiologicheskoe issledovanie: «Sovremennaia sistema vysshego obrazovaniia glazami studentov, aspirantov i professorsko-prepodavatel'skogo sostava MGU imeni M. V. Lomonosova». Vysshaia shkola sovremennykh sotsial'nykb nauk (fakul'tet) MGU imeni M. V. Lomonosova [online] Available at: http://vshssn.msu.ru/nauka-3/ (access data: 12.06.2016). (In Russ.).

Konstitutsiia Rossiiskoi Federatsii. Konstitutsiia Rossiiskoi Federatsii [online] Available at: http://www.constitution.ru/10003000/10003000-3.htm (access data: 12.06.2016). (In Russ.).

Koniukhova, K. (2016) Novyi ministr obrazovaniia Ol'ga Vasil'eva rasskazala, chto dal'she budet s EGE i vuzami. Komsomol'skaia pravda, 24 August [online] Available at: http://www. kp.ru/daily/26573.4/3588042 (access data: 25.08.2016). (In Russ.).

Nauchnye shkoly Moskovskogo gosudarstvennogo tekbnicheskogo universiteta im. N. E. Baumana: Istoriia razvitiia (1995), K. S. Kolesnikov, ed. I. B. Fedorov. Moscow, MGTU im. N. E. Baumana Publ. 439 p. (In Russ.).

Rasporiazhenie Pravitel'stva Rossiiskoi Federatsii ot 29 maia 2015 g. № 996-r g. Moskva «Strategiia razvitiia vospitaniia v Rossiiskoi Federatsii na period do 2025 goda» (2015). Rossiiskaia gazeta. Federal'nyi vypusk, no. 6693 (122) [online] Available at: https://rg.ru/ 2015/06/08/vospitanie-dok.html (access data: 12.06.2016). (In Russ.).

Russo, Zh.-Zh. (1912) Emil', ili O vospitanii, transl. by French. St. Petersburg, Izd-vo gazety «Shkola i zhizn’». 491 p. (In Russ.). 
Smit, A. (1962) Issledovanie o prirode i prichinakb bogatstva narodov. Moscow, Izd-vo sotsial'no-ekonomicheskoi literatury. 655 p. (In Russ.).

Toffler, E. (1997) Futuroshok, trensl. by English. Moscow, Lan'. 461 p. (In Russ.).

Submission data: 02.09.2016.

Ильинский Игорь Михайлович - доктор философских наук, профессор, ректор Московского гуманитарного университета, президент Национального союза негосударственных вузов, президент Союза негосударственных вузов Москвы и Московской области. Адрес: 111395, Россия, г. Москва, ул. Юности, д. 5. Тел.: +7 (499) 374-78-78. Эл. адрес: iilinskiy@mosgu.ru

Ilinskiy Igor Mikhailovich, Doctor of Philosophy, Professor, Rector, Moscow University for the Humanities; President, National Union of Nongovernmental Institutions of Higher Education; President, Union of the Nongovernmental Higher Education Institutions of Moscow and Moscow Oblast. Postal address: 5 Yunosti St., 111395 Moscow, Russian Federation. Tel.: +7 (499) 374-78-78. E-mail: iilinskiy@mosgu.ru 